\title{
Different aspects of reproduction strategies in crayfish: A review
}

\author{
B. Yazicioglu ${ }^{1, \star}$, J. Reynolds ${ }^{2}$ and P. Kozák ${ }^{1}$
}

${ }^{1}$ University of South Bohemia in České Budějovice, Faculty of Fisheries and Protection of Waters, South Bohemian Research Centre of Aquaculture and Biodiversity of Hydrocenoses, Zátiší 728/II, 38925 Vodňany, Czech Republic

${ }^{2}$ Former Fellow, Trinity College, University of Dublin, Ireland; current address 115 Weirview Drive, Stillorgan, Co. Dublin, Ireland

Received April 28, 2016 - Revised June 17, 2016 - Accepted June 26, 2016

\begin{abstract}
Study of the reproductive strategy of crayfish species is of great importance in the current astacological world. Crayfish are among the largest freshwater invertebrates, and as keystone species, they are able to regulate the structure of the benthic fauna in the freshwaters, demonstrating different ecological strategies and life spans ranging up to $20+$ years. In order to bring together the various pieces of information related to this issue, this overview of published scientific reports was conducted. The majority of crayfish species studied show sexual dimorphism, with approximately equal numbers of males and females. However, over some decades numerous observations have been made for a few species that may have different modes of reproduction, such as hermaphroditism or intersex (e.g. Cherax quadricarinatus, Samastacus spinifrons, Parastacus virilastacus and Pacifastacus leniusculus) and parthenogenesis (only Procambarus fallax f. virginalis). A recent study showed a new case of parthenogenesis as apomictic parthenogenesis (only Orconectes limosus). In addition, there are many investigations into the reproduction biology of crayfish, including using eyestalk ablation or androgenic gland ablation under various lab conditions and hybridization under natural conditions (e.g. Astacus astacus X Astacus leptodactylus, Orconectes rusticus X Orconectes propinquus). There are also some chemical factors which could possibly affect the reproduction system of crayfish in the wild.
\end{abstract}

Key-words: crustacea / parthenogenesis / intersex / hybridization

Résumé - Différents aspects des stratégies de reproduction des écrevisses : une revue. L'étude de la stratégie de reproduction des espèces d'écrevisses est d'une grande importance dans le monde astacicole actuel. Les écrevisses sont parmi les plus grands invertébrés d'eau douce, et comme des espèces clés, elles sont capables de réguler la structure de la faune benthique dans les eaux douces, présentant différentes stratégies écologiques et des durées de vie allant jusqu'à 20 ans. Afin de réunir les différents éléments d'information relatifs à cette question, une revue des publications scientifiques a été conduite. La majorité des espèces d'écrevisses étudiées montrent un dimorphisme sexuel, avec un nombre approximativement égal de mâles et de femelles. Cependant, depuis quelques décennies, de nombreuses observations ont été faites pour quelques espèces qui peuvent avoir différents modes de reproduction, tels que l'hermaphrodisme ou l'intersexe (par exemple Cherax quadricarinatus, Samastacus spinifrons, Parastacus virilastacus et Pacifastacus leniusculus) et la parthénogenèse (seulement Procambarus fallax $f$. virginalis). Une étude récente a montré un nouveau cas de parthénogenèse, une parthénogenèse apomictique (seulement Orconectes limosus). En outre, il y a beaucoup de recherches sur la biologie de la reproduction de l'écrevisse, y compris celle de l'ablation du pédoncule oculaire ou ablation de la glande androgène dans diverses conditions de laboratoire et de l'hybridation dans des conditions naturelles (par exemple Astacus astacus X Astacus leptodactylus, Orconectes rusticus X Orconectes propinquus). Il y a aussi des facteurs chimiques qui pourraient éventuellement avoir une incidence sur le système de reproduction des écrevisses à l'état sauvage.

Mots-clés : crustacés / parthénogénèse / intersexualité / hybridation

\section{Introduction}

Reproductive patterns in crustaceans are relatively diverse with most species exhibiting separate sexes (Chang and Sagi, 2008; Parnes et al., 2008; Nagaraju, 2011). Crustacea

^ Corresponding author: yazicioglu@frov.jcu.cz encompass approximately 233 families that contain 2725 genera and with fossil and extant species 17635 species (Grave et al., 2009; González-Tizón et al., 2013). The normal mode of reproduction for the Decapoda, the largest and most diversified group of the malacostracan Crustacea, is with separate sexes (Charniaux-Cotton, 1975). However, there are numerous deviations from this basic principle either for the entire species 
(Bauer and Holt, 1998), for certain populations of a species (Rudolph, 2002), or for some individuals (Sagi et al., 2002).

Freshwater crayfish of the order Decapoda (McLay and López Greco, 2011) are keystone species and due to their trophic activities they may have a considerable biological impact on the environment. Crayfish are currently divided into 4 superfamilies, 5 families, 44 genera and 653 species (Bracken-Grissom et al., 2014) with diversity being highest in North America and Australia (Holdich, 2002). All families (Astacidae, Parastacidae) are monophyletic except the Cambaridae (Bracken-Grissom et al., 2014). However, the numbers of crayfish species are disputable because several new species are described every year (e.g. Cherax (Cherax) subterigneus, Cambarus (Hiaticambarus) longirostris) (Patoka et al., 2015; Jones, 2016).

This report attempts to summarize the more unusual crayfish reproductive patterns varying from gonochorism such as parthenogenesis, intersex and hermaphroditism and describing some factors that could affect their genesis. In addition, there are hybridizations and manipulations (e.g. ablation of eyestalk and androgenic gland) which directly affect crayfish reproductive behaviour.

\section{Sexual reproduction in the crayfish}

The normal crayfish reproduction strategy is gonochorism where each individual has only one sex: male or female. The gonads, testis or ovary, whose size and appearance depend on the age and reproductive cycle of the individuals, lie dorsally in the thorax between the layer of the pericardial sinus and the hindgut. During the breeding season the internal reproductive organs enlarge significantly. The vas deferens takes on a milkywhite colour due to the production of sperm masses while the ovary becomes full of eggs, whose colour can be yellowishbrown or dark blue (Ďuriš et al., 2015).

The testis, the site of spermatogenesis and its final stage, spermiogenesis, is covered with a cortex of connective tissue and is composed of seminiferous tubules. The spermatocytes and spermatids develop gradually during the first and second meiotic division from spermatogonia (Ďuriš et al., 2015). A highly convoluted vas deferens arises from each side of the testis and opens at the gonopore on the basis of the fifth pereopod. The vas deferens is responsible for packaging the spermatozoa into spermatophores and for conducting the spermatophores to the gonopods (Vogt, 2002). The ovary is trilobed and has one straight oviduct on each side that opens to the outside on the bases of the third pereopods. In the ovary oogenesis takes place that finally produces large, centrolecithal eggs. The oviducts lead the ova down to the gonopores. Crayfish have external fertilization (Hamr, 2002). As is well known, there are differences between the crayfish families in their genital morphology (e.g. summarized in Reynolds and Souty-Grosset, 2012).

In astacids and parastacids the spermatophores are deposited either on the ventral surface of the female, or into the annulus ventralis which is known as a sperm storage chamber in cambarids that is located between the fourth and fifth pereiopods (Andrews, 1906a; Hobbs et al., 1977), during the mating period (Hamr, 2002). Cambarid (males and females)
(Hobbs, 1989; Wetzel, 2002; Buřič et al., 2010) and astacids (males and females) (Buřič et al., 2015) are cyclically dimorphic. The mating period is characterized by increased activity when sexually mature adult individuals actively seek their partners (Buřič et al., 2009). The behaviour is hormonally controlled and influenced by stimuli which are, above all, water temperature and photoperiod (Dubé and Portelance, 1992; Reynolds, 2002).

Egg laying from the oviduct of the female is stimulated by the mating itself as well as by other effects such as a decrease in water temperature or creating short daylight by photoperiod (Skurdal and Taugbol, 2002). The time period between copulation and ovulation varies, ranging from days to weeks (Vogt, 2002) or even several months (Buřič et al., 2013). A dense secretion is released from glair glands that dissolves spermatophore wall and releases spermatozoa across the abdominal part of the female body. These spermatozoa subsequently fertilize eggs which are released through the gonopores. The eggs a attach to the pleopods of female for brooding (Hamr, 2002; Niksirat et al., 2014b, 2015a).

\section{Biology of gametes in the crayfish}

The spermatozoon is produced in the process of spermatogenesis inside the testis that consists of two and three lobes in parastacids and astacids, respectively (Rudolph, 1995a,b). After completion of spermatogenesis, spermatozoa arrive into the two convoluted vasa deferentia, originating from each side of the testis and opening at the gonopore on the basis of the fifth pereopod (Vogt, 2002). Although the vasa deferentia are mainly known to be responsible for packaging the spermatozoa into spermatophores, it has been reported that in red swamp crayfish Procambarus clarkii the acrosomal spike on the anterior part of the spermatozoon is developed in the vas deferens (Niksirat et al., 2013a).

Spermatozoal cell ultrastructure has been successfully studied in taxonomic and phylogenetic studies across many animal taxa, including crustaceans (Felgenhauer, 1991; Medina, 1994; Tudge, 1995; Jamieson et al., 1995a, b; Jamieson and Tudge, 2000; Martin and Davis, 2001; Tirelli et al., 2008; Tudge, 2009; Niksirat et al., 2013b). Apart from its taxonomic and phylogenetic importance, knowledge of spermatozoal morphology can contribute to understanding the complex mechanisms of acrosome reaction and gamete fertilization (Simeo et al., 2010). The acrosome complex and nucleus are located at the anterior and posterior of the crayfish spermatozoon, respectively. A comparison with the acrosome dimensions of studied crayfish species shows that representatives of Parastacidae have a smaller acrosome compared to Cambaridae. The representatives of Astacidae show the largest acrosome within the three families of crayfish (Jamieson and Tudge, 2000; Niksirat et al., 2013a, b; Kouba et al., 2015).

The acrosome complex organelle is divided into two main parts: the main body of the acrosome that is a dense inverted cup-shaped structure organized into three layers of differing electron densities and extended parallel filaments, and the sub-acrosome zone occupying the central part of the acrosome complex, divided into two electron dense areas. An acrosome spike in the spermatozoon, also called the 
horn-like process or anterior acrosomal process, has been reported in spermatozoa of Cambaroides japonicus (Yasuzumi and Lee, 1966), Cambarus sp. (Anderson and Ellis, 1967), Procambarus leonensis, (Felgenhauer and Abele, 1991) and Procambarus clarkii (Niksirat et al., 2013a). Microtubular radial arms are visible on each side of the acrosome or nucleus in sagittal view and wrap around the spermatozoon and are extended into the nucleus (Niksirat et al., 2013a, b). Radial arms are present in the Astacidae and Cambaridae but are absent in the parastacids Cherax tenuimanus, C. albidus, red claw C. quadricarinatus and the yabby $C$. destructor (Beach and Talbot, 1987; Kouba et al., 2015). All organelles of the crayfish spermatozoon are tightly enclosed in an extracellular capsule. It has been suggested that the capsule confines the radial arms and permits tighter packaging of the sperm in the spermatophores (Dudenhausen and Talbot, 1983); this is supported by the absence of such capsules in Cherax species where radial arms are lacking (Beach and Talbot, 1987; Vogt, 2002). The decapod spermatozoon does not have a true flagellum as in other animals and is non-motile (Jamieson and Tudge, 2000; Tudge, 2009). The microtubules within each arm are not arranged in the $9+2$ axonemal pattern typical of the flagellated tails of spermatozoa of other animals. Therefore, they are not responsible for sperm movement (Tudge, 2009; Poljaroen et al., 2010). One hundred and fifty proteins from nine different categories have been identified in the signal crayfish $P$. leniusculus spermatophore, the most diverse categories in the protein profile being cytoskeleton proteins including actin and tubulin (Niksirat et al., 2014a).

The spermatophore in astacids consists of a spermatophore wall with three different layers, which covers a central sperm mass (Dudenhausen and Talbot, 1983; Vogt, 2002; Niksirat et al., 2015b). A sticky layer covers the surface of freshly ejaculated spermatophore and helps attachment of the spermatophore to the body of a female until fertilization (Dudenhausen and Talbot, 1983; Niksirat et al., 2014b). The freshly ejaculated spermatophore is soft in decapods, but after mating it becomes hardened to protect the sperm mass (Malek and Bawab, 1971; Uma and Subramoniam, 1979). Post-mating spermatophore storage in crayfish and other decapods is accompanied by morphological and molecular changes that are necessary for the spermatozoon to develop fertilizing ability (Alfaro et al., 2003; Vanichviriyakit et al., 2004; Alfaro et al., 2007; López Greco and Lo Nostro, 2008; Aungsuchawan et al., 2011; Braga et al., 2014; Niksirat et al., 2014b, 2015b).

Extensive morphological changes associated with postmating storage have been observed in the spermatophore of the crayfish, including changes in the morphology of spermatophore wall components and spermatozoon organelles such as plasma membrane and subacrosome zone (Dudenhausen and Talbot, 1983; Niksirat et al., 2014b). These changes occur after release of the spermatozoon from the capsule, especially the formation of the filament/droplet structure, may contribute to the mechanism of egg-spermatozoon binding in the narrow-clawed crayfish A. leptodactylus (Niksirat et al., 2014b). Subcellular localization of calcium in the noble crayfish spermatophore using oxalate-pyroantimonate techniques showed that calcium plays important roles in the postmating spermatophore hardening and spermatozoon capaci- tation. The post-mating changes in the calcium distribution may happen because of some secretions from the end part of the vas deferens which are added to the spermatophore just before ejaculation, or through contact with ambient water (Niksirat and Kouba, 2016). Extensive proteomic changes occur during post mating storage of noble crayfish A. astacus, on the body surface of the female. The concentration of several proteins in the protein profile of male gametes changes significantly during storage on the body surface of the female, indicating post-mating final maturation of the spermatozoon (Niksirat et al., 2015b).

As egg laying approaches, the female lies back and secretes glair from glands located on the abdomen surface of the body. These secretions dissolve the spermatophore wall and scatter spermatozoa across the ventral abdomen a few hours before egg release. This high viscosity secretion prevents spermatozoa from being washed away until the end of fertilization. The female forms a brood chamber by curling the abdomen to keep the spermatozoa and eggs floating in the glair secretions (Andrews, 1906b; Niksirat et al., 2014b).

Different types of vesicles, including some that are highly or moderately electron-dense, occur in the cortex of the noble crayfish oocyte. One hour post-spawning, the first envelope, especially its inner layer, is condensed. The highly and moderately dense vesicles discharge their contents into the perivitelline space, where they combine and form a second envelope around the egg. Twenty-four hours post-ovulation, a second envelope is visible in the perivitelline space and the outer part of the egg cortex (Niksirat et al., 2015a). In crayfish, fertilized eggs are attached to the pleopods of females until hatching (Andrews, 1906b). The egg attachment stalk in the noble crayfish is derived from the first envelope (Niksirat et al., 2015a).

\section{Unusual reproduction strategies}

\subsection{Parthenogenesis}

In the Crustacea, parthenogenesis is frequent among entomostracan groups such as Anostraca, Cladocera, Conchostraca and Ostracoda (Bell, 1982; Suomalainen et al., 1987; Vogt et al., 2004); Sassaman (1995) reviewed sex determination and evolution of unisexuality in the Conchostraca. Malacostracan crustaceans are primarily gonochoristic with sex that is genetically determined (Charniaux-Cotton, 1975). Exceptions are some parasitic and free-living isopods and amphipods whose sex is determined environmentally (Adams et al., 1987; Vogt et al., 2004). For parthenogenesis in malacostracans confirmed examples are limited (Suomalainen, 1950; Bell, 1982; Suomalainen et al., 1987; Gruner, 1993). In addition, the occurrence of parthenogenesis is suspected in some tanaidaceans and amphipods, e.g., Corophium bonelli, as males have never been found (Gruner, 1993).

Sexuality in crayfish has recently been extended by the discovery of the first case of parthenogenesis in the marbled crayfish (Scholtz et al., 2003), which was initially suspected to be a hermaphrodite. Marbled crayfish Procambarus fallax (Hagen, 1870) f. virginalis (Martin et al., 2010) is the only obligate parthenogenetic decapod known to date (Scholtz et al., 2003). 
It first appeared in the German aquarium trade in the midnineties, and since then it has become popular and widespread due to rapid reproduction and easy handling which resulted in its releases to open waters in several countries particularly in Europe (Kouba et al., 2014). The first identification of their previous morphological and genetic data argue for an assignment of the marbled crayfish to the North American Cambaridae, and more specifically, to the large and diverse genus Procambarus (Scholtz et al., 2003). Of the cambarid species included in their genetic analysis relationship the closest species was the similar-looking Procambarus fallax. Difficulties in the identification of the marbled crayfish are basically related to the fact that cambarid crayfish are largely determined on the basis of the male gonopods (Hobbs, 1972, 1989), lacking in exclusively all-female marbled crayfish stocks (Vogt et al., 2004). Investigation of the development of the external female characters in the marbled crayfish was first performed using a scanning electron microscope, covering life stages from hatchling to repeatedly spawned adult. The first external female character unambiguously recognized is the annulus ventralis, which emerges in stage 4 juveniles, and both annulus ventralis and gonopores appear completely sculptured in adolescents of $\sim 2 \mathrm{~cm}$ TL, being only slightly transformed thereafter (Vogt et al., 2004). The observed increase in a number of acuminate and pappose setae of putative mechanoreceptive function (Hobbs, 1972; 1989) around the gonopores and the annulus during maturation had not been described before in decapods (Vogt et al., 2004). Martin et al. (2015) recently showed that the marbled crayfish is a triploid, showing a triple amount of the haploid number of chromosomes. In addition, they detected a huge amount of a subtelocentric chromosome which became clear firstly in haploid and secondly in diploid cells of sexual individuals of the $P$. fallax complex. In the parthenogenetic marbled crayfish, this featured chromosome occurs thrice (Martin et al., 2015). For the marbled crayfish this origin of parthenogenesis is remote, however, no pre-existing parthenogenetic forms are known in the Astacidae (Vogt et al., 2004). Additionally, Vogt (2007) showed that exposure of crayfish eggs to $17 \alpha$-methyl testosterone did not change female reproduction organs and secondary sex characters, also there were no discernible effects on early ovarian development.

In a study of cross-breeding and parentage analysis, Vogt et al. (2015) showed that marbled crayfish and $P$. fallax are different cases of the reproduction strategy. Procambarus fallax (Hagen, 1870) f. virginalis could be a new species but they originate from $P$. fallax by triploidisation and concomitant epigenetic alterations, evidence from using morphological, behavioural, genetic and epigenetic studies. Marbled crayfish is morphologically very similar to the parent species but has superior fitness traits. Genetic data suggest an instantaneous speciation by autopolyploidisation and parallel change of the mode of reproduction from gonochorism to parthenogenesis. Consequently, the $P$. fallax-marbled crayfish pair provides an interesting new model system to study asexual speciation and saltational evolution in animals and to determine how much genetic and epigenetic change is necessary to create a new species.
With the exception of the marbled crayfish, with its obligatory reproduction by apomictic parthenogenesis (Martin et al., 2007), the only other decapod species for which a potential for asexual reproduction has been suggested are the red swamp crayfish P. clarkii (Yue et al., 2008) and spiny-cheek crayfish O. limosus (Buřič et al., 2011). For the explanation of facultative parthenogenesis in $O$. limosus, these authors provided experimental evidence that females of the spiny-cheek crayfish are capable of facultative parthenogenesis. Such a reproductive mode has never before been recognized in decapods. Analyses with seven microsatellite loci showed that crayfish females kept physically separate from males, produced genetically homogeneous offspring identical with maternal individuals; this suggests they reproduced by apomixis, unlike those females which mated with males and had a diverse offspring. Also, according to Buřič et al. (2011) studies complemented by the genetic analysis of variable nuclear markers, prove that at least one species of cambarid crayfish is capable of facultative parthenogenesis. However, the possibility exists that this reproduction behaviour mode is more widespread among cambarids, and may contribute to the success of this group when colonizing new habitats and territories. Asexual generations may also have contributed to observations of supposed P. clarkii clones by Yue et al. (2008), and possibly to significant heterozygote deficiencies observed in Chinese populations of P. clarkii (Yue et al., 2010) as well as in some recent studies of existing invasive populations of $O$. limosus in the Czech Republic (Filipova et al., 2009), up to now explained by founder effects or assortative mating (Buřič et al., 2011, 2013).

\subsection{Intersexuality}

Intersexuality is characterized by the presence of male and female sexual characteristics in the same individual, in gonochoric or hermaphroditic species, and may be limited to the internal morphology or may extend to gonadal morphological differentiation (Sagi et al., 1996; Vogt, 2002; Noro et al., 2008). Variation from normal development of the androgenic gland (AG) frequently causes the development of some male properties. According to Duriš et al. (2001) a part of or almost the full complement of male gonopods was recorded in adult females of A. leptodactylus in mud lagoons in the Karviná District (Ďriš et al., 2015), while in South American crayfish of the genera Parastacus and Samastacus, the changes in development and activity of this gland occur probably in the background of intersex phenomena, i.e., sex changes in crayfish individuals (Rudolph and Almeida, 2000). Experimental insertion of fresh androgenic gland into a female crayfish body caused not only masculinization but also a change in her behaviour towards a male (Karplus et al., 2003).

From the literature on freshwater crayfish (Astacida), the most common deviation from separate sexes is intersexuality in all three families, the Astacidae, Cambaridae, and Parastacidae. At least 12 of the 29 crayfish genera (Vogt, 2002) are reported to include intersexuality. Among the Parastacidae, intersexuality has been determined in species from Oceania and South America. In the genus Parastacus of southern South America, simultaneous presence of male and 


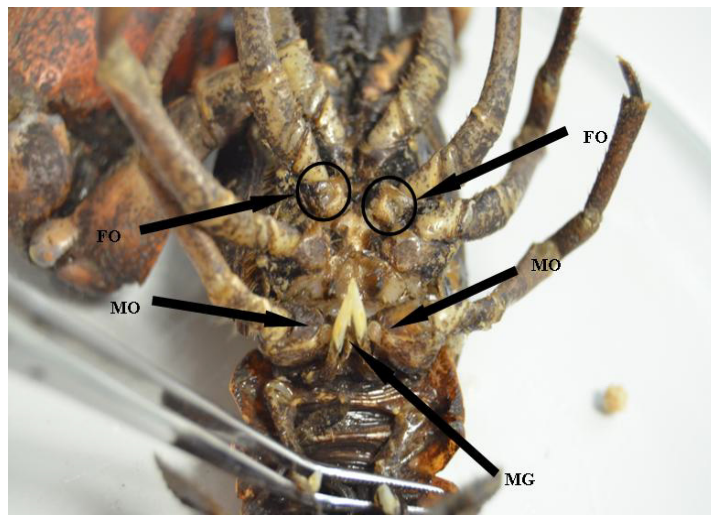

(a)

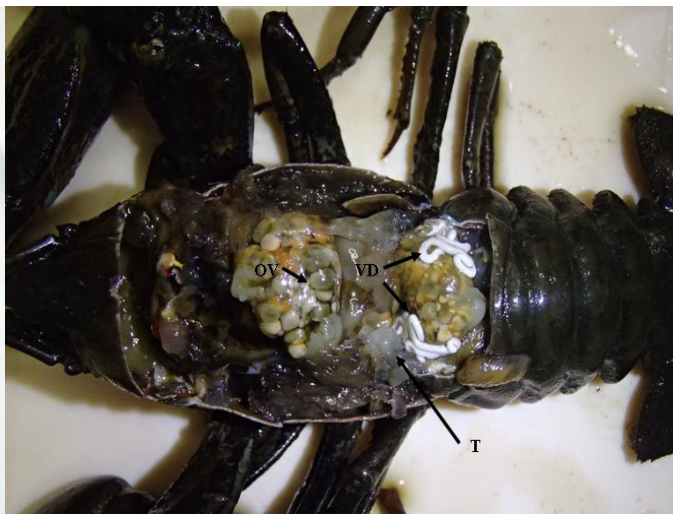

(b)

Fig. 1. Pasifastacus leniusculus. (a) Both male and female genital openings, as well as male gonopods, FO, female opening; MO, male opening; MG, male gonopods; (b) vasa deferentia (VD), ova (OV), testes (T) (Yazicioglu et al., 2014).

female gonopores is a common characteristic (Rudolph and Almeida, 2000). Although intersexuality is common among parastacids and is a strong indication of the occurrence of hermaphroditism, functional hermaphroditism is rare among crayfish and is of the protandric type, as in Samastacus spinifrons and Parastacus nikoleti (Rudolph, 1995a; Noro et al., 2008). With some individuals having gonopores of both sexes the Chilean species $P$. nicoleti is an exception (Rudolph, 1995a). Intersexuality is also observed in species of Parastacidae, namely of Parastacus pilimanus and P. brasiliensis (Rudolph and Almedia, 2000). For the other two South American genera, namely Samastacus and Virilastacus, the literature points to the presence of only one pair of gonopores in each individual. In Oceania, intersexuality is also seen in the Australian genera Engaewa, Engaeus, Euastacus and Cherax (Horwitz, 1988; Sokol, 1988; Medley, 1993; Sagi et al., 1996).

Although the frequency of intersex individuals showing external male and female characters is often less than $1 \%$, in some species, e.g. C. quadricarinatus, higher percentages, up to $14 \%$, have been recorded (Sagi et al., 2002). Medley et al. (1994) report a normal testis and a previtellogenic ovary in a single C. quadricarinatus intersex individual and describe it on the basis of histological examinations as a case of "true hermaphroditism". They report one intersex individual that had a right-side male genital opening and two female genital openings and functioned as a male, siring a batch of offspring. However, Sagi et al. (1996) mention that an ovary exists in C. quadricarinatus only when a female genital opening is present in the absence of a male genital opening on the same side. Rudolph (2002) collected intersexed specimens of $S$. spinifrons from rivers in Chile and in the description of a new species, Virilastacus rucapihulensis, Rudolph and Crandall (2005) note the presence of specimens with extra gonopores.

Yazicioglu et al. (2014) report the first evidence of intersex in the astacid signal crayfish, P. leniusculus (Fig. 1). An intersexual specimen's morphology shows both male and female genital openings, as well as male gonopods. Also, histology reveals both spermatocytes and oocytes. Among the cambarids, Kozák et al. (2007) reported that during the mating season of
O. limosus the male spermatophores were predominantly filled with spermatozoa and sperm was also noted in the vas deferens. However, two out of 15 males sampled during the winter were found to be intersex, in which atretic oogonia and oocytes were present at the periphery of testicular tissue and occupied less than $15 \%$ of testicular tissue. The evidence of intersex strongly suggested transitional stages of a gradual change of sex, which may be qualified as partial hermaphroditism.

\subsection{Hermaphroditisim}

Hermaphrodites are individuals that have a functional male and female reproductive system at some time during their lives (Ghiselin, 1969). There are two major types of hermaphroditism, which have received considerable study (Michiels, 1998).

(a) Simultaneous hermaphroditism: both sexes are present simultaneously.

(b) Sequential hermaphroditism: sex change during life; a change from male to female is called protandry (e.g. Amphiprioninae, some sea anemones and certain freshwater limpets) and sex change from female to male is protogyny (e.g. certain fish species in the families Serranidae and Sparidae, also some isopods and tanaid crustaceans).

As was mentioned above, intersex individuals showing male and female characters occur regularly in low frequencies in a number of crayfish species, particularly in the Parastacidae, however, functional sequential hermaphroditism (Rudolph, $1995 \mathrm{a}$ ) is very rare among crayfish and is protandric (Rudolph, 1995a, Table 1). On the other hand, the intersex individuals in natural populations of decapods may also be associated with non-functional hermaphroditism (Sagi et al., 1996). Functional protandric hermaphroditism is only known for P. nicoleti and S. spinifrons (Rudolph and Almeida, 2000; Rudolph, 2002). Interestingly, only the fluvial populations of $S$. spinifrons included protandric hermaphrodites, but not the lake populations. An extensive analysis of 10 populations of S. spinifrons revealed that of the 1114 specimens sampled 597 
Table 1. Overview of unusual reproduction strategies in some crayfish species.

\begin{tabular}{|c|c|c|c|}
\hline Family & Species & Reproduction strategy & References \\
\hline Astacidae & Pacifastacus leniusculus & Intersexuality & Yazicioglu et al., 2014 \\
\hline \multirow{5}{*}{ Cambaridae } & Procambarus fallax & Parthenogenesis & Scholtz et al., 2003 \\
\cline { 2 - 4 } & f. virginalis (Marbled crayfish) & & Taketomi et al., 1996 \\
\cline { 2 - 4 } & Procambarus clarkii & Intersexuality & Buřič et al., 2011; \\
& Orconectes limosus & Kacultative parthenogenesis, et al., 2007 \\
\hline \multirow{5}{*}{ Parastacidae } & Intersexuality & Rudolph, 1995b; \\
& Samastacus spinifrons & Intersexuality, & Rudolph and Almedia, 2000 \\
\cline { 2 - 4 } & Parastacus pugnax & Partial protandric hermaphroditism & Rudolph and Almedia, 2000 \\
\cline { 2 - 4 } & Parastacus varicosus & Intersexuality & Rudolph and Almedia, 2000 \\
\cline { 2 - 4 } & Parastacus pilimanus & Intersexuality & Rudolph and Almedia, 2000 \\
\cline { 2 - 4 } & Parastacus defosus & Intersexuality & Rudolph and Almedia, 2000 \\
\cline { 2 - 4 } & Parastacus saffordi & Intersexuality & Rudolph and Almedia, 2000 \\
\cline { 2 - 4 } & Cherax quadricarinatus & Hermaphroditism, Intersexuality & Sagi et al., 2002; Parnes et al., 2003 \\
\cline { 2 - 4 } & Virilastacus & Intersexuality & Rudolph and Rivas, 1988; \\
& araucanius & Martinez et al., 1994 \\
\cline { 2 - 4 } & Virilastacus rucapihuelensis & Partial protandric hermaphroditism & Rudolph and Crandall, 2005 \\
\cline { 2 - 4 } & Parastacus brasiliensis & Hermaphroditism & Almedia and Buckup, 2000 \\
\cline { 2 - 4 } & Parastacus nicoleti & Partial protandric hermaphroditism & Rudolph, 1995a; \\
& & & Rudolph and Almedia, 2000 \\
\hline
\end{tabular}

were males, 476 females, and 41 intersexes. All of the intersexes had gonoducts of both sexes but 30 specimens had only testes, 4 had only ovaries, and 7 had ovotestes.

\section{Laboratory manipulations: effect of eyestalk ablation and androgenic gland ablation on reproductive behaviour of crayfish}

The androgenic gland (AG) is present in embryos and juvenile crayfish of both sexes, but it is specially developed in males. It is found in the male's vas deferens as an important glandular structure. The androgenic gland hormones control the so-called masculinization of the body, i.e., growth and development of the body in male proportions, but it also supports the production of spermatozoa in the testes. In females, it causes inhibition of differentiation of their body (Sagi and Khalaila, 2001; Ďuriš et al., 2015).

Male differentiation and primary and secondary characteristics in crustaceans are regulated by the AG. In gonochoristic crustaceans, the AG is also linked to intersexuality. Whereas the co-occurrence of various male and female characteristics is demonstrated in intersex crustaceans, there are only a few studies on sexually dimorphic behaviour patterns in such individuals (Barki et al., 2006) Sexual differentiation in crustaceans is hormonally controlled by the androgenic hormone(s) (AGH) secreted by the AG (Charniaux-Cotton and Payen, 1985). During early development, AG primordia are expressed in genetic males and they determine the development of masculine gametogenic (testes) and endocrine (AG) organs - distinct organs in crustaceans. Consequently, the endocrine function of the AG regulates the development of male phenotypic characteristics (Charniaux-Cotton and Payen, 1988; Katakura, 1989; Payen, 1990; Sagi et al., 1997). The AG is also implicated in the mediation of intersexuality, although causative factors vary among crustacean species and are unclear in some cases (Barki et al., 2006).

In isopods, on the other hand, it is argued that intersex individuals, functional males, are the product of a delayed expression/action of AGH in genetic males (Azzouna et al., 2004). It is also known that endocrine-disrupting pollutants cause de-masculinization and intersexuality in amphipods, probably by interfering with the function of the AG (Ford et al., 2004). Therefore, it is clear that AG, which is responsible for the control of male primary and secondary sexual characteristics (including behaviour), is also a key factor in the formation of intersex individuals and sexual plasticity in crustaceans. As intersex individuals can be plastic in terms of sexually dimorphic behaviours and their responsiveness to sexrelated hormonal manipulations, they provide a useful model for inducible sexual plasticity for the analysis of hormonal control of sexually dimorphic behaviours in Crustacea (Sagi et al., 1996, 2002; Barki et al., 2006).

Neurohormones are part of the sinus gland-Y-organ endocrine axis and the sinus gland-mandibular organ endocrine axis, respectively (Fingerman, 1995; Aguilar et al., 1996; Liu and Laufer, 1996; Terauchi et al., 1996; Wainwright et al., 1996; Keller et al., 1999; Boecking et al., 2002). While the inhibitory effect of the eyestalk on the male reproductive system has been reported in some species, the identity and mode 
of action of the factor actually responsible for this inhibition are not yet known. It is concluded that the secretory product(s) of the AG is proteinaceous in nature. Early support for this proposition may be found in the considerable amount of proteins in the cytoplasmic secretory vesicles of the AG of the crab Pachygrapsus crassipes (King, 1964). The ultrastructure of the AG of $P$. clarkii also supports the possibility of a proteinaceous secretion (Miyawaki and Taketomi, 1978; Taketomi, 1986). Some histological evidence in the Giant river prawn Macrobrachium rosenbergii supports the idea of a proteinaceous androgenic hormone (Awari and Dube, 1999). As is the case for all peptide hormones, the target tissue is expected to have specific cell-surface receptors. Therefore, a presumably proteinaceous hormone such as AG should initiate multiple signal transduction pathways that change the activation of kinases or phosphatases on specific proteins in its target organ, namely the testis.

In decapod crustaceans, both male and female, the $\mathrm{X}$-organ-sinus gland complex in the eyestalk produces the neurohormones that regulate various physiological processes (Tan-Fermin, 1991; Keller, 1992; Wilder et al., 1994; Sagi et al., 1997). The effect of such neurohormones on male reproduction is less known than that of the female. On the other hand, it is well-known that while regulation of the male reproductive system is controlled by AG (Charniaux-Cotton and Payen, 1988; Sagi et al., 1997; Sagi and Khalaila, 2001), the initiation, completion, and intensity of spermatogenic activity are regulated by circulating AG hormone (Charniaux-Cotton and Payen, 1988). In some decapod species, spermatogenesis initiates only after the AGs are fully developed (Taketomi et al., 1996). In the male prawn, M. rosenbergii (Nagamine et al., 1980), and in intersex individuals of the Australian red claw crayfish, Cherax quadricarinatus, the removal of AG leads to cessation or regression of spermatogenesis (Khalaila et al., 2002).

According to Sagi et al. (2002) studies reveal that eyestalk ablation in the mature $C$. quadricarinatus male leads to hypertrophy of AG. Hypertrophy of AG is determined by increases in its size and weight and by the enrichment of the polypeptide profile of the AG. These results are consistent with the literature in a number of decapod crustaceans of hypertrophy of AG combined with hyperactivity and increase in RNA synthesis after eyestalk ablation (Hoffman, 1968; Foulks and Hoffman, 1974; Adiyodi, 1984; Kulkarni et al., 1984). Several polypeptides that are expressed in AGs of eyestalkablated $C$. quadricarinatus males necessitate further studies based on previous findings regarding the identified glycosylated AG hormone found in the isopod Armadillidium vulgare (Okuno et al., 1997; Martin et al., 1999; Okuno et al., 1999; Sagi and Khalaila, 2001) as in addition to the general effect of eyestalk ablation on protein synthesis, it can cause overexpression of specific polypeptides representing androgenic factors. Eyestalk ablation also causes dynamic changes in the reproductive system of mature $C$. quadricarinatus males. As far as is known, descriptions of similar dynamic processes on crustaceans are missing in the literature (Sagi et al., 2002). After eyestalk ablation, there is a gradual and significant increase in the weight of the sperm duct due to accumulation in the sperm duct of spermatophores ready for ejaculation. This accumula- tion is an indicator of the potency of the spermiation process following eyestalk removal. Further evidence for the enhancement of spermiation is provided by the decrease in the amount of DNA in the testes from the second week onward and by the significantly higher number of empty spermatogenic lobules found in testicular sections of eyestalk-ablated males' testes versus those of intact animals. It is probable that the enhanced spermiation process leads to a decrease in the weight of the testes in the third and fourth weeks after eyestalk ablation that is parallel with previous findings in $C$. quadricarinatus (Khalaila et al., 2002). The decrease in testis weight is also consistent with previous findings in the prawn Parapenaeopsis hardwickii (Kulkarni et al., 1984; Manor et al., 2004).

Recently, for the first time direct evidence for masculinization effects of AG on agonistic and mating behaviour was found in decapod crustaceans (Karplus et al., 2003; Barki et al., 2006), in addition to its morphological, anatomical and physiological effects (Khalaila et al., 2002; Manor et al., 2004; Barki et al., 2006). While previous studies explored the masculinization effects on behaviour of implanting AGs into C. quadricarinatus females, current studies used the intersex model for investigating the de-masculinization effects of AG ablation (Barki et al., 2006).

\section{Factors possibly affecting the genesis of unusual reproduction in crayfish: hybridization}

In crayfish, males may copulate not only with conspecific females but also with females of congeners (Reynolds, 2002). Therefore, the existence of fertile crayfish hybrids in the wild is not surprising (Hogger, 1988). In the literature the first hybridization instance between indigenous and invading crayfish was between two crayfish of European origin, the astacid crayfish A. astacus and A. leptodactylus (Cukerzis, 1968). Furrer et al. (1999) obtained hybrid offspring between A. astacus males and $A$. leptodactylus females. In the opposite case $(A$. astacus females X A. leptodactylus males), A. astacus females lost eggs after interbreeding. As reported in Mlinarec et al. (2011), no hybrid population between A. astacus and A. leptodactylus are known in nature. Despite earlier reports, a potential hybrid between two native crayfish species, A. astacus and A. leptodactylus, was proved using a morphological approach in Mrežnica River, Croatia (Maguire et al., 2013). In addition, Jelić et al. (2013) proposed that mixed populations of noble ( $A$. astacus) and narrow-clawed crayfish (A. leptodactylus) could be come across in Europe. They tested the possibility of hybridisation in two interspecific mating combinations under lab condition twice, in two mating seasons. According to their first results, mating was successful, but the majority of females had lost their eggs or died. At the end of their experiment, hybrids with A. leptodactylus females had successful interspecific mating, but there was no success with conspecifically mated $A$. leptodactylus (Jelić et al., 2013). The same types of experiments were also done by our group but without success in obtaining hybrid juveniles. Only egg laying and maybe partly developing embryos were observed in some cases (P. Kozák, unpublished). 
Generally, hybridization in cambarid crayfish has relatively rarely been observed, exceptions being hybridization between $O$. rusticus and $O$. limosus in a small stream of N-central Massachusetts (Smith, 1981), and hybridization between Cambarus robustus and $C$. bartonii in New York (Crocker, 1957; Smith, 1979), also hybridization between the native species $O$. propinquus and the introduced species $O$. obscurus and O. rusticus in New York and Ontario (Crocker, 1957; Crocker and Barr, 1968). The evidence of morphological features of hybridization between the $O$. juvenilis and $O$. cristavarius in the Kentucky River basin was reported by MacDonald et al. (2006). A more recent study on unique genetic documentation is provided by Perry et al. (2001, 2002) for hybridization between native and invasive Orconectes species (Cambaridae). They compared crayfish from allopatric and sympatric populations of the invasive $O$. rusticus and of the indigenous $O$. propinquus (Girard) and $O$. virilis (Hagen) in Wisconsin (USA) by utilizing diagnostic nuclear and mitochondrial DNA markers along with morphological data (Gherardi, 2007). In sympatric sites hybridization occurs between $O$. rusticus and $O$. propinquus while no hybridization occurs between $O$. virilis and either of these species. A detailed study on the dynamics of hybridization conducted in Trout Lake, Country revealed that over $6 \%$ of crayfish were F1 hybrids, $4 \%$ were F2 individuals (hybrid $\times$ hybrid origin), and $13 \%$ were backcrosses (product of hybrid $\times$ parental mating) (Perry et al., 2001). The majority of F1 hybrids $(95 \%)$ were the result of $O$. rusticus females mating with $O$. propinquus males; only $1 \%$ of the total crayfish population was the product of $\mathrm{F} 1$ hybrids backcrossing to $O$. propinquus, whereas $13 \%$ represented backcrosses to $O$. rusticus. Hence F1 hybrids appeared to mate disproportionately with pure $O$. rusticus that cause greater genetic introgression of nuclear DNA form $O$. propinquus to $O$. rusticus than in the reverse direction. The result is the gradual elimination of $O$. propinquus genes from the population (Gherardi, 2007). There are also another hybridization report between native (O. sanbornii) and invasive (O. rusticus) species in the Huron River in north-central Ohio based on a combination of molecular markers such as nuclear DNA, mitochondrial DNA and allozymes (Zuber et al., 2012). Their results showed that while there are no differences between the species at nuclear DNA loci, mtDNA and allozyme loci confirmed the presence of individuals of hybrid ancestry. On the other hand, they also found preliminary evidence of possible mitochondrial recombination and biparental inheritance and examination of morphological features of both species in sympatry and allopatry and confirmed species-diagnostic morphological features including gonopod traits and shape of the annulus ventralis.

Lawrence et al. (2000) have obtained hybrids between the parastacids Cherax rotundus females and C. albidus males that constantly produced only male progeny. This unanticipated finding underlines the resilience of crayfish sexuality. Hence it is possible that the parthenogenetic marbled crayfish might be the result of hybridization of two unidentified cambarids. Hybridization may have occurred both in nature and in the aquarium. Parthenogenesis of a contagious origin, that is the hybridization of females from a pre-existing parthenogenetic lineage with males of either the same or a closely re- lated species, is common in brine shrimp and ostracods and generally results in polyploid unisexuals (Simon et al., 2003). The critically endangered hairy marron, Cherax tenuimanus, an endemic species in the Margaret River, Western Australia, is being rapidly replaced by the invasive smooth marron, C. cainii (Bunn et al., 2008). According to Imgrund (1998) the hairy and smooth marron in the Margaret River mate and their hybrids also have the distinctive setation of the hairy Margaret River marron. Additionally, Lawrence (2002) showed, based on the fertilization of hybrids, that it is possible to determine hybrid fertility, and mentioned that identification of hybrids is possible using microsatellites but not by morphological methods.

All these findings led to wide morphological evidence of putative hybrids among crayfish species (Perry et al., 2002). The implication of the study of Perry et al. (2002) is clear that hybridization and introgression pose a substantial threat to the conservation of crayfish biodiversity and that further research is required into the potential for hybridization among resident and invasive species. Such studies would have the potential to predict species at risk of losing their genetic identity (Gherardi, 2007).

\section{Chemical factors}

There is still no consensus on whether genetic (population or individual) or phenotypic (environmental) factors are more important in the control of fecundity and successful reproduction. Current knowledge suggests that phenotypic variation is considerable, yet the selection of breeding stock should not be ruled out. The timing of breeding may be related in part to water temperature, but the initiation of mating and spawning may occur at different temperatures and dates, suggesting that a timing mechanism seems to be involved, which can be reset to some extent by continued high temperatures (Reynolds, 2002).

The phenotype of an organism is determined by the genes, the environment and by stochastic developmental events (Vogt et al., 2008). Vogt et al. (2008) stated that, even in the same environment, individual genotypes can produce different phenotypes because of developmental variation, resulted in generating variability among clone-mates and individuality in a parthenogenetic species. This developmental variation, an apparently ubiquitous phenomenon in living beings, can introduce elements of randomness into life histories, altering individual fitness and subsequently population dynamics.

Many aspects of crayfish reproduction are still unknown, such as the endocrine control of reproduction in astacid crayfish. Pheromones may be crucial in attracting mates and stimulating mating. Other hormones are no doubt significant in controlling brooding behaviour, including inhibiting maternal cannibalism, and related knowledge may be crucial in astaciculture (Reynolds, 2002). Sex is determined and irreversibly fixed during embryonic or larval development in response to particular environmental cues in invertebrates (Adams et al., 1987); in crayfish unusual reproduction strategies may also have occurred. Future studies should address the possible mechanisms triggering abnormal reproductive biology in crayfish, including whether environmental pollution 
Table 2. Some examples of unusual reproduction strategies in freshwater vertebrates and invertebrates.

\begin{tabular}{|c|c|c|c|c|}
\hline & Family & Species & Reproduction strategy & References \\
\hline \multirow{3}{*}{ Vertebrate } & Cyprinidae & Rutilus rutilus & Intersexuality & Jobling et al., 1998 \\
\hline & Gasterosteidae & Gasterosteus aculeatus & Intersexuality & Borg and Van den Hurk, 1983 \\
\hline & Acipenseridae & Scaphirhynchus platorynchus & Intersexuality & Harshbarger et al., 2000 \\
\hline \multirow{15}{*}{ Invertebrate } & Margelopsidae & Margelopsis haeckeli & Parthenogenetic & Werner, 1955 \\
\hline & Alcyoniidae & Alcyonium hiberniculum & Parthenogenetic & Hartnoll, 1977 \\
\hline & Lasaeidae & Lasaea australis & Hermaphrodite & O'Foighil, 1988 \\
\hline & $\begin{array}{c}\text { Thiaridae } \\
\text { Pachychilidae }\end{array}$ & $\begin{array}{c}\text { Aylacostoma sp., Melanoides sp., } \\
\text { Tarebia } \text { sp., Thiara sp., and Sulcospira sp. }\end{array}$ & Parthenogenetic & Morrison, 1954 \\
\hline & Paludomidae & $\begin{array}{l}\text { Bathanalia sp., Tanganyicia sp. } \\
\text { and Tiphobia } \text { sp. }\end{array}$ & Parthenogenetic & Moore, 1898 \\
\hline & Tateidae & Potamopyrgus sp. & Parthenogenetic & Winterbourn, 1970 \\
\hline & Hydrobiidae & Potamopyrgus antipodarum & Parthenogenetic & Jokela et al., 1997 \\
\hline & Viviparidae & Campeloma decisum & Parthenogenetic & Johnson, 1992 \\
\hline & Sphaeromatidae & Gnorimosphaeroma naktongense & Protogynous hermaphroditism & Abe and Fukuhara, 1996 \\
\hline & Sphaeromatidae & Gnorimosphaeroma oregonense & Protandry hermaphroditism & Brook et al., 1994 \\
\hline & Cyprididae & Cyprinotus incongruens & Unisexual & Turgeon and Hebert, 1994 \\
\hline & Daphniidae & Daphnia pulex & Parthenogenetic & Hebert et al., 1983 \\
\hline & Littorinidae & Littorina littorea & Intersex & Schulte-Oehlmann et al., 1998 \\
\hline & Artemiidae & $\begin{array}{c}\text { Artemia salina } \\
\text { and } A \text {. parthenogenetica }\end{array}$ & Parthenogenetic & $\begin{array}{c}\text { Browne, 1992; } \\
\text { Golubev et al., } 2001\end{array}$ \\
\hline & Atyidae & Paratya curvirostris & Protandry hermaphroditism & Carpenter et al., 1978 \\
\hline
\end{tabular}

may be responsible for it in some instances. Researches reveal that some DDTs (dichloro diphenyl trichloroethanes) and brominated flame retardants can disrupt the endocrine system in aquatic animals (Hajslova et al., 2007; Havelková et al., 2007). Although crayfish become more widely used in toxicological studies (Kouba et al., 2012), the impacts on sex determination and reproduction systems remain largely unstudied. Although biochemical changes may be expected in testes or ovaries, the exposure is too short to see impacts on reproduction (Velisek et al., 2013).

\section{Conclusions}

Unusual reproductive strategies, such as hermaphrodites and parthenogenesis in crustaceans, especially in crayfish, have been demonstrated. In most of the studies in the literature, intersexuality in crayfish is a non-functional hermaphroditism supposedly induced by damage to or disturbances of the androgenic gland that determine the male sex via hormones. Although such individuals often have ovotestes, they act as males since the ovarian portion of the gonad remains arrested in a previtellogenic state.

Only the marble crayfish is known as a parthenogenetic species up to now, however spiny-cheek crayfish and some other species can under some specific conditions reproduce partenogenetically as well. On one hand, hybridization could be an effective tool in aquaculture production and it is well demonstrated in several crayfish species. On the other hand, the development of new parthenogenetic species by interspecific hybridization is well established by molecular evidence for gastropods ostracods and reptiles (see Table 2). Such lineages, mostly polyploid and due to heterosis effects, often have a broad environmental tolerance. As mentioned by Parker et al. (1999) and Gherardi (2007), invader species, such as the American crayfish species now occurring in Europe, may cause an indirect genetic effect on native species, subsequently resulting in transformed patterns of natural selection or gene flow within these species. Invaders may change selection regimes or disrupt gene flow due to their fragmentation of indigenous species populations, leading them to risky bottlenecks. Hybridization between a non-indigenous and an indigenous species may cause a direct effect that may have three possible results: (1) the emergence of a new invader genotype; (2) the production of sterile hybrids with a resulting waste of gametes and resource competition with indigenous species; and (3) the hybrid may become dominant in natural habitats, leading to a virtual extinction of indigenous taxa through "genetic pollution". In the last point, there is a possibility that chemical factors may influence the release of different reproductive strategies in crayfish.

Published and unpublished data show that it is possible to come across abnormalities in reproductive patterns in crayfish, even in Crustacea, either by chance in the wild or under laboratory conditions through experimentation. Additionally, many factors such as laboratory manipulations, hybridization or pollution may lead to changes not only in the reproduction system but also other systems of crayfish. Studies are needed to help 
further evaluation and understanding of triggering factors of unusual reproduction strategies.

Acknowledgements. TThis study was supported by the Ministry of Education, Youth and Sports of the Czech Republic - projects, CENAKVA" (No. CZ.1.05/2.1.00/01.0024), "CENAKVA II" (No. LO1205 under the NPU I program) and by the Grant Agency of the University of South Bohemia (No. 017/2016/Z).

\section{References}

Abe M. and Fukuhara H., 1996. Protogynous hermaphroditism in the brackish and freshwater isopod, Gnorimosphaeroma naktongense (Crustacea: Isopoda, Sphaeromatidae). Zool. Sci., 13(2), 325-329.

Adams J., Greenwood P. and Naylor C., 1987. Evolutionary aspects of environmental sex determination. Int. J. Inver. Rep. Dev., 11, $123-135$

Adiyodi R.G., 1984. Seasonal changes and the role of eyestalks in the activity of the androgenic gland of the crab, Paratelphusa hydrodromous (Herbst). Comp. Physiol. Ecol., 9, 427-431.

Aguilar M.B., Falchetto R., Shabanowitz J., Hunt D.F. and Huberman A., 1996. Complete primary structure of the molt-inhibiting hormone (MIH) of the Mexican crayfish Procambarus bouvieri (Ortmann). Peptides, 17, 367-374.

Alfaro J., Muñoz N., Vargas M. and Komen J., 2003. Induction of sperm activation in open and closed thelycum penaeoid shrimps. Aquaculture, 216, 371-381.

Alfaro J., Ulate K. and Vargas M., 2007. Sperm maturation and capacitation in the open thelycum shrimp Litopenaeus (Crustacea: Decapoda: Penaeoidea). Aquaculture, 270, 436-442.

Almeida A.O. and Buckup L., 2000. Occurrence of protandric hermaphroditism in a population of the neotropical freshwater crayfish Parastacus brasiliensis (Parastacidae). J. Crustacean Biol., 20, 224-230.

Anderson W.A. and Ellis R.A., 1967. Cytodifferentiation of the crayfish spermatozoon: acrosome formation, transformation of mitochondria and development of microtubules. Z. Zellforsch. Mik. Ana., 77, 80-94.

Andrews E.A. 1906a. The annulus ventralis. Proc. Boston Soc. Nat. Hist., 32, 427-479.

Andrews E.A., 1906b. Egg-laying of crayfish. Am. Nat., 40, 343-356.

Aungsuchawan S., Browdy C.L. and Withyachumnarnkul B., 2011. Sperm capacitation of the shrimp Litopenaeus vannamei. Aquacult. Res., 42, 188-195.

Awari S.A. and Dube K., 1999. Histological and histochemical study of androgenic gland of Macrobrachium rosenbergii (DE MAN). J. Aquat. Trop., 14, 101-112.

Azzouna A., Greve P. and Martin G., 2004. Sexual differentiation traits in functional males with female genital apertures (male symbol fga) in the woodlice Armadillidium vulgare Latr. (Isopoda, Crustacea). Gen. Comp. Endocrinol., 138, 42-49.

Barki A., Karplus I., Manor R. and Sagi A., 2006. Intersexuality and behavior in crayfish: The de-masculinization effects of androgenic gland ablation. Horm. Behav., 50, 322-331.

Beach D. and Talbot P., 1987. Ultrastructural Comparison of Sperm from the Crayfishes Cherax tenuimanus and Cherax albidus. J. Crustacean Biol., 7, 205-218.
Bell G., 1982. The masterpiece of nature. The evolution and genetics of sexuality. Univ. of California Pr., June, 1982.

Boecking D., Dircksen H. and Keller R., 2002. The crustacean peptides of the $\mathrm{CHH} / \mathrm{MIH} / \mathrm{GIH}$ family. In: Wiese K. (ed.), The Crustacean Nervous System. Springer-Verlag, Heidelberg, pp. 84-97.

Borg B. and van den Hurk R., 1983. Oocytes in the testes of the threespined stickleback, Gasterosteus aculeatus. Copeia, 1983(1), 259-261.

Bracken-Grissom H.D., Ahyong S.T., Wilkinson R.D., Feldmann R.M., Schweitzer C.E., Breinholt J.W., Bendall M., Palero F., Chan T.Y., Felder D.L., Robles R., Chu K.H., Tsang L.M., Kim D., Martin J.W. and Crandall K.A., 2014. The emergence of lobsters: phylogenetic relationships, morphological evolution and divergence time comparisons of an ancient group (decapoda: achelata, astacidea, glypheidea, polychelida). Syst. Biol., 63, 457-479.

Braga A., Suita de Castro A.L., Poersch H.L. and Wasielesky W., 2014. Spermatozoal capacitation of pink shrimp Farfantepenaeus paulensis. Aquaculture, 430, 207-210.

Brook H.J., Rawlings T.A. and Davies R.W., 1994. Protogynous sex change in the intertidal isopod Gnorimosphaeroma oregonense (Crustacea: Isopoda). Biol. Bull., 187(1), 99-111.

Browne R.A., 1992. Population genetics and ecology of Artemia: insights into parthenogenetic reproduction. Trends Ecol. Evol., 7, 232-237.

Bunn J.J., Koenders A., Austin C.M. and Horwitz P., 2008. Identification of Hairy, Smooth And Hybrid Marron (Decapoda: Parastacidae) in the Margaret River: Morphology And Allozymes.

Buřič M., Kouba A. and Kozák P., 2009. Spring mating period in Orconectes limosus: the reason for movement. Aquat. Sci., 71, 473-477.

Buřič M., Kouba A. and Kozák P. 2010. Intra-sex dimorphism in crayfish females. Zoology, 113, 301-307.

Buřič M., Hulák M., Kouba A., Petrusek A. and Kozák P., 2011. A successful crayfish invader is capable of facultative parthenogenesis: A novel reproductive mode in decapod crustaceans. PloS One, 6, e20281.

Buřič M., Kouba A. and Kozák P., 2013. Reproductive plasticity in freshwater invader: from long-term sperm storage to parthenogenesis. PloS one, 8, e77597.

Buřič M., Veselý L. and Kouba A. 2015. Molting and growth of adult signal crayfish Pacifastacus leniusculus (Dana 1852): Effective investments due to seasonal morphological changes? European Crayfish Conference Research and Management, 9th-12th April, Landau, Germany, Abstract book, p. 61.

Carpenter A., 1978. Protandry in the freshwater shrimp, Paratya curvirostris (Heller, 1862) (Decapoda: Atyidae), with a review of the phenomenon and its significance in the Decapoda. $J . R$. Soc. N. Z., 8(4), 343-358.

Chang E.S. and Sagi A., 2008. Male reproductive hormones. In: Mente E. (ed.), Reproductive biology of crustaceans. Science Publishers, Enfield, NH.

Charniaux-Cotton H., 1975. Hermaphroditism and gynandromorphism in malacostracan crustacea. In: Reinboth R. (ed.), Intersexuality in the Animal Kingdom. Springer, Berlin, Heidelberg, pp. 91-105. 
Charniaux-Cotton H. and Payen G., 1985. Sexual differentiation. Mantel L.H. (ed.), In The Biology of Crustacea. Academic Press, Orlando, Florida, pp. 217-299.

Charniaux-Cotton H. and Payen G., 1988. Crustacean reproduction. In: Laufer H. and Downer R.G.H. (eds.), Endocrinology of Selected Invertebrate Types. A.R. Liss, New York, 279-303.

Crocker D.W., 1957. The crayfishes of New York (Decapoda: Astacidae). New York State Mus., Sci. Serv., Bull., 355, 1-97.

Crocker D.W. and Barr D.W., 1968. Handbook of the crayfishes of Ontario. published for Royal Ontario Museum by University of Toronto Press.

Cukerzis J., 1968. Interspecific relations between Astacus astacus L. and A. leptoductylus Esch. Pañstwowe Wydawnictwo Naukowe.

Dubé P. and Portelance B., 1992. Temperature and photoperiod effects on ovarian maturation and egg laying of the crayfish, Orconectes limosus. Aquaculture, 102, 161-168.

Dudenhausen E.E. and Talbot P., 1983. An ultrastructural comparison of soft and hardened spermatophores from the crayfish Pacifastacus leniusculus Dana. Can. J. Zoolog., 61, 182-194.

Duriš Z., Horká I. and Vavricek O., 2001. K populacni ekologii raku na Karvinsku (On population ecology of crayfish in the Karvina District). Biologie Ekologie, 8, 118-126.

Duriš z., Horká I. and Kozák P., 2015. Morphology and Anatomy of Crayfish. In: Kozák P. (ed.), Crayfish Biology and Culture. University of South Bohemia in Ceske Budejovice, Faculty of Fisheries and Protection of Waters, Vodnany, Czech Republic, pp. 165-200.

Felgenhauer B.E. and Abele L.G., 1991. Morphological diversity of decapod spermatozoa. In: Bauer R.T. and Martin J.W. (eds.), Crustacean Sexual Biology. Columbia University Press, New York, NY, pp. 322-341.

Filipova L., Kozubikova E. and Petrusek A., 2009. Allozyme variation in Czech populations of the invasive spiny-cheek crayfish Orconectes limosus (Cambaridae). Knowl. Manag. Aquat. Ecosyst., 10, 394-395.

Fingerman M., 1995. Endocrine Mechanisms in Crayfish, with Emphasis on Reproduction and Neurotransmitter Regulation of Hormone Release. Am. Zool., 35, 68-78.

Ford A.T., Fernandes T.F., Rider S.A., Read P.A., Robinson C.D. and Davies I.M., 2004. Endocrine disruption in a marine amphipod? Field observations of intersexuality and de-masculinisation. Mar. Environ. Res., 58, 169-173.

Foulks N.B. and Hoffman D.L., 1974. The effects of eyestalk ablation and B-ecdysone on RNA synthesis in the androgenic glands of the protandric shrimp, Pandalus platyceros Brandt. Gen. Comp. Endocrinol., 22, 439-447.

Furrer S.C., Cantieni M. and Duvoisin N., 1999. Freshly hatched hybrids between Astacus astacus and Astacus leptodactylus differ in chela shape from purebred offspring. Freshw. Crayfish, 12, 90-97.

Gherardi F., 2007. Biological invaders in inland waters: Profiles, distribution and threats. Quarterly Rev. Biol., 44, 504-542.

Ghiselin M.T., 1969. The evolution of hermaphroditism among animals. Quarterly Rev. Biol., 189-208.

Golubev, A.P., Khmeleva, N.N., Alekhnovich, A.V., Roshchina, N.N. and Stolyarova, S.A., 2001. Influence of reproduction on variability of life history parameters in Artemia salina (Crustacea, Anostraca). Entomological Review, 81(1), 96.
González-Tizón A.M., Rojo V., Menini E., Torrecilla Z. and Martínez-Lage A., 2013. Karyological analysis of the shrimp (Decapoda: Palaemonidae). J. Crustacean Biol., 33, 843-848.

Grave D.S., Pentcheff N.D., Ahyong S.T., Chan T.Y., Crandall K.A., Dworschak P.C., Felder D.L., Feldmann R.M., Fransen C.H.J.M., Goulding L.Y.D., Lemaitre R., Low M.E.Y., Martin J.W., Ng P.K.L., Schweitzer C.E., Tan S.H., Tshudy D. and Wetzer R., 2009. A classification of living and fossil genera of decapods crustaceans. Raff. Bull. Zool., 21, 1-109.

Gruner H.E., 1993. Crustacea. In: Gruner H.E. (ed.), Lehrbuch der Speziellen Zoologie. Band I, 4. Teil, Arthropoda. Jena, Gustav Fischer, pp. 448-1030.

Hajslova J., Pulkrabova J., Poustka J., Cajka T. and Randak T., 2007. Brominated flame retardants and related chlorinated persistent organic pollutants in fish from river Elbe and its main tributary Vltava. Chemosphere, 69, 1195-1203.

Hamr P., 2002. Biology of freshwater crayfish. In: Holdich D. (ed.), Blackwell Publishing Ltd., Oxford.

Harshbarger, J.C., Coffey, M.J. and Young, M.Y., 2000. Intersexes in Mississippi river shovelnose sturgeon sampled below Saint Louis, Missouri, USA. Mar. Environ. Res., 50(1), 247-250.

Hartnoll, R.G., 1977. Reproductive strategy in two British species of Alcyonium. In: Biology of benthic organisms: 11th European symposium on marine biology, Galway, 321-328.

Havelková M., Randák T., Žlábek V., Krijt J., Kroupová H., Pulkrabová J. and Svobodová Z., 2007. Biochemical markers for assessing aquatic contamination. Sensors-Basel, 7, 2599-2611.

Hebert P.D.N. and Crease T., 1983. Clonal diversity in populations of Daphnia pulex reproducing by obligate parthenogenesis. Heredity, 51(1), 353-369.

Hobbs H.H.Jr., 1972. Crayfishes (Astacidae) of North and Middle America. Biota of freshwater ecosystems, identification manual 9. US Environmental Protection Agency, Washington, DC.

Hobbs, H.H.Jr., Hobbs, H.H.III. and Daniel, M.A. 1977. A review of the troglobitic decapod crustaceans of the Americas. Smithsonian Institution Press., No. 244.

Hobbs H.H.J.Jr., 1989. An illustrated checklist of the American crayfishes (Decapoda: Astacidae, Cambaridae, and Parastacidae). Washington, D.C.: Smithsonian Institution Press.

Hoffman D.L., 1968. Seasonal Eyestalk Inhibition on the Androgenic Glands of a Protandric Shrimp. Nature, 218, 170-172.

Hogger J.B., 1988. Ecology, population biology and behaviour. Freshwater crayfish: biology, management and exploitation. Croom Helm, London.

Holdich D.M., 2002. Background and Functional Morphology. In: Holdich D.M. (ed.), Biology of freshwater crayfish, Blackwell, Oxford, Chapter 1, p. 29.

Horwitz P., 1988. Secondary sexual characteristics of females of the freshwater crayfish genus Engaeus (Decapoda, Parastacidae). Crustaceana, 54, 25-32.

Imgrund J.A., 1998. Population Genetic Analysis of the Freshwater Crayfish, Cherax tenuimanus. IUCN 2001. IUCN Red List Categories and Criteria: Version 3.1., IUCN Species Survival Commission. IUCN, Gland, Switzerland and Cambridge, UK.

Jamieson B.G.M. and Tudge C.C., 2000. Crustacea-Decapoda. In: Jamieson B.G.M. (ed.), Progress in Male Gamete Ultrastructure and Phylogeny, Reproductive Biology of the Invertebrates. Chichester, 9, 1-95. 
Jamieson B.G.M., Ausio J. and Justine J.-L., 1995a. Advances in spermatozoal phylogeny and taxonomy. Mémoires du Muséum National d'Histoire Naturelle (Paris), 166, 343-358.

Jamieson B.G.M., Guinot D. and Richer de Forges B., 1995b. Phylogeny of the Brachyura (Crustacea, Decapoda): evidence from spermatozoal ultrastructure. In: Jamieson B.G.M., Ausio J. and Justine J.L. (eds.), Advances in spermatozoal phylogeny and taxonomy. Mémoires du Méusum National d'Histoire Naturelle (Paris), 166, 265-283.

Jelić M., Klobucar G., Bláha M. and Maguire I., 2013. Noble and narrow-clawed crayfish hybridisation experiment in natural habitat. Regional European Crayfish meeting (CrayCro). September 26-28, Rovinj, Croatia.

Jobling S., Nolan M., Tyler C.R., Brighty G. and Sumpter J.P., 1998. Widespread sexual disruption in wild fish. Environ. Sci. Technol., 32(17), 2498-2506.

Johnson S.G., 1992. Spontaneous and hybrid origins of parthenogenesis in Campeloma decisum (freshwater prosobranch snail). Heredity, 68(3), 253-261.

Jokela J., Lively C.M., Dybdahl M.F. and Fox J.A., 1997. Evidence for a cost of sex in the freshwater snail Potamopyrgus antipodarum. Ecology, 78, 452-460.

Jones D.R., 2016. A New Crayfish of the Genus Cambarus (Decapoda: Cambaridae) From the Flint River Drainage in Northern Alabama and South Central Tennessee, USA. Zootaxa, 4103, 43-53.

Karplus I., Sagi A., Khalaila I. and Barki A., 2003. The Influence of Androgenic Gland Implantation on the Agonistic Behavior of Female Crayfish (Cherax quadricarinatus) in Interactions with Males. Behaviour, 140, 649-663.

Katakura Y., 1989. Endocrine and genetic control of sex differentiation in the Malacostracan Crustacea. Invertebr. Reprod. Dev., 16, 177-181.

Keller R., 1992. Crustacean neuropeptides: Structures, functions and comparative aspects. Experientia, 48, 439-448.

Keller R., Kegel G., Reichwein B., Sedlmeier D. and Soyez D., 1999. Biological effects of neurohormones of the $\mathrm{CHH} / \mathrm{MIH} / \mathrm{GIH}$ peptide family in crustaceans. In: Roubos E.W., Wendelaar-Bonga S.E., Vaudry H. and DeLoof A. (eds.), Recent Developments in Comparative Endocrinology and Neurobiology. Shaker, Maastricht, pp. 209-212.

Khalaila I., Manor R., Weil S., Granot Y., Keller R. and Sagi A., 2002. The eyestalk-androgenic gland-testis endocrine axis in the crayfish Cherax quadricarinatus. Gen. Comp. Endocrinol., 127, $147-156$.

King D.S., 1964. Fine structure of the androgenic gland of the crab, Pachygrapsus crassipes. Gen. Comp. Endocrinol., 4, 533-544.

Kouba A., Kuklina I., Niksirat H., Máchová J. and Kozák P., 2012. Tolerance of signal crayfish (Pacifastacus leniusculus) to Persteril 36 supports use of peracetic acid in astaciculture. Aquaculture, 350, 71-74.

Kouba A., Petrusek A. and Kozák P., 2014. Continental-wide distribution of crayfish species in Europe: update and maps. Knowl. Manag. Aquat. Ecosyst., 413, 5.

Kouba A., Niksirat H. and Bláha M., 2015. Comparative ultrastructure of spermatozoa of the redclaw Cherax quadricarinatus and the yabby Cherax destructor (Decapoda, Parastacidae). Micron, $69,56-61$.
Kozák P., Hulák M., Policar T. and Tichy F., 2007. Studies of annual gonadal development and gonadal ultrastructure in spiny-cheek crayfish (Orconectes limosus). BFPP/Bull. Fr. Pêche Piscic., 384, 15-26.

Kulkarni G.K., Nagabhushanam R. and Joshi P.K., 1984. Neuroendocrine control of reproduction in the male penaeid prawn, Parapenaeopsis hardwickii (Miers) (Crustacea, Decapoda, Penaeidae). Hydrobiologia, 108, 281-289.

Lawrence C., 2002. Margaret River Marron: morphology and hybrids. In: Molony, B. (ed.), Scientific Workshop on the Margaret River Marron, Perth, Australie, 20-23.

Lawrence C.S., Morrissy N.M., Vercoe P.E. and Williams I.H., 2000. Hybridization in australian freshwater crayfish production of allmale progeny. J. World Aquacult. Soc., 31, 651-658.

Liu L. and Laufer H., 1996. Isolation and characterization of sinus gland neuropeptides with both mandibular organ inhibiting and hyperglycemic effects from the spider crab Libinia emarginata. Arch. Insect. Biochem., 32, 375-385.

López Greco L.S. and Lo Nostro F.L., 2008. Structural changes in the spermatophore of the freshwater 'red claw' crayfish Cherax quadricarinatus (Von Martens, 1898) (Decapoda, Parastacidae). Acta Zool-Stockholm., 89, 149-155.

MacDonald L., Bulach B., Stamper R. and Ziemba R., 2006. Hybridization Between the Crayfishes Orconectes juvenilis and Orconectes cristavarius in the Kentucky River Basin: Morphological Evidence.

Maguire I., Špelić I., Jelić M. and Klobučar G., 2013. Is it Possible to Detect Narrow-clawed and Noble crayfish Probable Hybrids Using Multivariate Discriminant Analysis of Morphometric Data? Freshwater Crayfish, 19, 219-227.

Malek S.R.A. and Bawab F.M., 1971. Tanning in the spermatophore of a crustacean (Penaeus trisulcatus). Experientia, 27, 1098-1098.

Manor R., Aflalo E.D., Segall C., Weil S., Azulay D., Ventura T. and Sagi A., 2004. Androgenic gland implantation promotes growth and inhibits vitellogenesis in Cherax quadricarinatus females held in individual compartments. Invertebr. Reprod. Dev., 45, 151-159.

Martin G., Sorokine O., Moniatte M., Bulet P., Hetru C. and Van Dorsselaer A., 1999. The structure of a glycosylated protein hormone responsible for sex determination in the isopod, Armadillidium vulgare. Eur. J. Biochem., 262, 727-736.

Martin J.W. and Davis G.E., 2001. An updated classification of the recent Crustacean. Science Series No. 39. Natural History Museum of Los Angeles County, 124.

Martin P., Kohlmann K. and Scholtz G., 2007. The parthenogenetic Marmorkrebs (marbled crayfish) produces genetically uniform offspring. Naturwissenschaften, 94, 843-846.

Martin P., Dorn N.J., Kawai T., van der Heiden C. and Scholtz G., 2010. The enigmatic Marmorkrebs (marbled crayfish) is the parthenogenetic form of Procambarus fallax (Hagen, 1870). Contrib. Zool., 79, 107-118.

Martin P., Thonagel S. and Scholtz G., 2015. The parthenogenetic Marmorkrebs (Malacostraca: Decapoda: Cambaridae) is a triploid organism. J. Zool. Syst. Evol. Res., 54, 13-21.

Martínez R.I., Llanos F.E. and Quezada A.E., 1994. Samastacus araucanius (Faxon, 1914): aspectos morfológicos de un nuevo registro para Chile (Crustacea, Decapoda, Parastacidae). Gayana Zool., 58, 9-15. 
McLay C.L. and López Greco L.S., 2011. A hypothesis about the origin of sperm storage in the Eubrachyura, the effects of seminal receptacle structure on mating strategies and the evolution of crab diversity: How did a race to be first become a race to be last? Zool. Anz., 250, 378-406.

Medina A., 1994. Spermiogenesis and sperm structure in the shrimp Parapenaeus longirostris (Crustacea: Dendrobranchiata): comparative aspects among decapods. Mar. Biol., 119, 449-460.

Medley P.B. and Rouse D.B., 1993. Intersex australian red claw crayfish (Cherax quadricarinatus). J. Shellfish Res., 12, 93-94.

Medley P., Camus A., Tiersch T. and Avault J.W., 1994. Hermaphroditic Australian redclaw crayfish (Cherax quadricarinatus). Int. Assoc. Astacology, 10th Symposium, 50.

Michiels N.K., 1998. Mating conflicts and sperm competition in simultaneous hermaphrodites. In: Birkhead T.R. and Møller A.P. (eds.), Sperm competition and sexual selection. Academic Press, London, pp. 219-254.

Miyawaki M. and Taketomi Y., 1978. The Occurrence of an Extended Perinuclear Space in Androgenic Gland Cells of the Crayfish, Procambarus clarki. Cytologia, 43, 351-355.

Mlinarec, J., Mcžić, M., Pavlica, M., Šrut, M., Klobučar, G., and Maguire, I., 2011. Comparative karyotype investigations in the European crayfish Astacus astacus and A. leptodactylus (Decapoda, Astacidae). Crustaceana, 84, 1497-1510.

Moore J.E.S., 1898. The mollusks of the great African lakes. II. The anatomy of the Typhobias, with a description of the new genus (Batanalia). Q. J. Microsc. Sci. 41, 181-204.

Morrison J.P., 1954. The relationships of old and new world melanians. Smithsonian Inst., United States National Museum, 103, 357-394.

Nagamine C.M., Knight A.W., Maggenti A. and Paxman G., 1980. Effects of androgenic gland ablation on male promary and secondary sexual characteristics in the Malaysian prawn Macrachium rosenbergii (De Man) (Decapoda, Palamonidae), with first evidence of induced feminization in a nonhermaphroditic decapod. Gen. Comp. Endocrinol., 41, 423-441.

Nagaraju G.P., 2011. Reproductive regulators in decapod crustaceans: an overview. J. Exp. Biol., 214, 3-16.

Niksirat H. and Kouba A., 2016, Subcellular localization of calcium deposits in the noble crayfish Astacus astacus spermatophore: Implications for post-mating spermatophore hardening and spermatozoon maturation. J. Morphol., 277, 445-452.

Niksirat H., Kouba A., Pšenička M., Kuklina I. and Kozák P., 2013a. Ultrastructure of spermatozoa from three genera of crayfish Orconectes, Procambarus and Astacus (Decapoda: Astacoidea): New findings and comparisons. Zool. Anz., 252, 226-233.

Niksirat H., Kouba A., Rodina M. and Kozák P., 2013b. Comparative ultrastructure of the spermatozoa of three crayfish species: Austropotamobius torrentium, Pacifastacus leniusculus, and Astacus astacus (Decapoda: Astacidae). J. Morphol., 274, 750-758.

Niksirat H., Andersson L., James P., Kouba A. and Kozák P., 2014a. Proteomic profiling of the signal crayfish Pacifastacus leniusculus egg and spermatophore. Anim. Reprod. Sci., 149, 335-344.

Niksirat H., Kouba A. and Kozák P., 2014b. Post-mating morphological changes in the spermatozoon and spermatophore wall of the crayfish Astacus leptodactylus: insight into a non-motile spermatozoon. Anim. Reprod. Sci., 149, 325-334.
Niksirat H., Kouba A. and Kozák P., 2015a. Ultrastructure of egg activation and cortical reaction in the noble crayfish Astacus astacus. Micron, 68, 115-121.

Niksirat H., James P., Andersson L., Kouba A. and Kozák P., $2015 b$. Label-free protein quantification in freshly ejaculated versus post-mating spermatophores of the noble crayfish Astacus astacus. J. Proteomics, 123, 70-77.

Noro C., López-Greco L.S. and Buckup L., 2008. Gonad morphology and type of sexuality in Parastacus defossus Faxon 1898, a burrowing, intersexed crayfish from southern Brazil (Decapoda: Parastacidae). Acta Zool-Stockholm, 89, 59-67.

O'Foighil, D., 1988. Random mating and planktotrophic larval development in the brooding hermaphroditic clam Lasaea australis (Lamarck, 1818). The Veliger, 31(3-4), 214-221.

Okuno A., Hasegawa Y. and Nagasawa H., 1997. Purification and Properties of Androgenic Gland Hormone from the Terrestrial Isopod Armadillidium vulgare. Zool. Sci., 14, 837-842.

Okuno A., Hasegawa Y., Ohira T., Katakura Y. and Nagasawa H., 1999. Characterization and cDNA cloning of androgenic gland hormone of the terrestrial isopod Armadillidium vulgare, Biochem. Biophys. Res. Commun., 264, 419-423.

Parker I.M., Simberloff D., Lonsdale W.M., Goodell K., Wonham M., Kareiva P.M., Williamson M.H., Von Holle B., Moyle P.B., Byers J.E. and Goldwasser L., 1999. Impact: Toward a Framework for Understanding the Ecological Effects of Invaders. Biol. Invasions, 1, 3-19.

Parnes S., Khalaila I., Hulata G. and Sagi A., 2003. Sex determination in crayfish: are intersex Cherax quadricarinatus (Decapoda, Parastacidae) genetically females? Genet. Res., 82, 107-116.

Parnes S., Raviv S. and Sagi A., 2008. Reproductive biology of crustaceans, Enfield, NH: Science Publishers.

Patoka J., Bláha M. and Kouba A., 2015. Cherax (Cherax) subterigneus, a new crayfish (Decapoda: Parastacidae) from West Papua, Indonesia. J. Crustacean Biol., 35, 830-838.

Payen G.G., 1990. Roles of androgenic gland hormone in determining the sexual characters in crustacea. In: Gupta A.P. (ed.), Morphogenetic Hormones of Arthropods. Roles in Histogenesis, Organogenesis, and Morphogenesis. Rutgers University Press, New Jersey, pp. 431-452.

Perry W.L., Feder J.L. and Lodge D.M., 2001. Implications of hybridization between introduced and resident Orconectes crayfishes. Conserv. Biol., 15, 1656-1666.

Perry W.L., Lodge D.M. and Feder J.L., 2002. Importance of hybridization between indigenous and nonindigenous freshwater species: An overlooked threat to North American biodiversity. Syst. Biol., 51, 255-275.

Poljaroen J., Vanichviriyakit R., Tinikul Y., Phoungpetchara I., Linthong V., Weerachatyanukul W. and Sobhon P., 2010. Spermatogenesis and distinctive mature sperm in the giant freshwater prawn, Macrobrachium rosenbergii (De Man, 1879). Zool. Anz., 249, 81-94.

Reynolds J.D. 2002. Growth and Reproduction. In: Holdich D.M. (ed.), Biology of Freshwater Crayfish. Blackwell Science, Oxford, pp. 152-191.

Reynolds J.D. and Souty-Grosset C., 2012. Crayfish as prime players in ecosystems: life- history strategies. In: Reynolds J.D. and Souty-Grosset C. (eds.), Management of Freshwater Biodiversity. Crayfish as bioindicators. Cambridge University Press, Cambridge, pp. 55-56. 
Rudolph E. and Almeida A., 2000. On the sexuality of South American Parastacidae (Crustacea, Decapoda). Invertebr. Reprod. Dev., 37, 249-257.

Rudolph E. and Crandall K., 2005. A new species of burrowing crayfish Virilastacus rucapihuelensis (Crustácea, Decapoda, Parastacidae) from southern Chile. Proc. Biol. Soc. Washington, $118,765-776$.

Rudolph E. and Rivas H., 1988. Nuevo hallazgo de Samastacus araucanius (Faxon, 1914) (Decapoda: Parastacidae). Biota, 4, 73-78.

Rudolph E.H., 1995a. Partial protandric hermaphroditism in the Burrowing Crayfish Parastacus nicoleti (Philippi, 1882) (Decapoda: Parastacidae). J. Crustacean Biol., 15, 720-732.

Rudolph E.H., 1995b. A case of gynandromorphism in the freshwater crayfish Samastacus spinifrons (Philippi, 1882)(Decapoda, Parastacidae). Crustaceana, 68, 705-711.

Rudolph E.H., 2002. New records of intersexuality in the freshwater crayfish Samastacus spinifrons (Decapoda, Parastacidae). J. Crustacean Biol., 22, 377-389.

Sagi A. and Khalaila I., 2001. The Crustacean Androgen: A Hormone in an Isopod and Androgenic Activity in Decapods. Am. Zool., 41, 477-484.

Sagi A., Khalaila I., Barki A., Hulata G. and Karplus I., 1996. Intersex red Claw crayfish, Cherax quadricarinatus (von Martens): Functional males with pre-Vitellogenic ovaries. Biol. Bull., 190, 16-23.

Sagi A., Snir E. and Khalaila I., 1997. Sexual differentiation in decapod crustaceans: role of the androgenic gland. Invertebr. Reprod. Dev., 31, 55-61.

Sagi A., Manor R., Segall C., Da Vis C. and Khalaila I., 2002. On intersexuality in the crayfish Cherax quadricarinatus: an inducible sexual plasticity model. Invertebr. Reprod. Dev., 41, 27-33.

Sassaman C., 1995. Sex determination and evolution of unisexuality in the Conchostraca. Hydrobiologia, 298, 45-65.

Scholtz G., Braband A., Tolley L., Reimann A., Mittmann B., Lukhaup C., Steuerwald F. and Vogt G., 2003. Ecology: Parthenogenesis in an outsider crayfish. Nature, 421, 806.

Schulte-Oehlmann U., Oehlmann J., Bauer B., Fioroni P., Leffler U.-S., 1998. Toxico-kinetic and -dynamic aspects of TBTinduced imposex in Hydrobia ulvae compared with intersex in Littorina littorea (Gastropoda, Prosobranchia). In: O'Riordan R.M., Burnell G.M., Davies M.S. and Ramsay N.F. (eds.), Aspects of Littorinid Biology: Proceedings of the Fifth International Symposium on Littorinid Biology, Cork, Ireland, 713 September 1996. Springer Netherlands, Dordrecht, 215-225.

Simeo C.G., Kurtz K., Rotllant G., Chiva M. and Ribes E., 2010. Sperm ultrastructure of the spider crab Maja brachydactyla (Decapoda: Brachyura). J. Morphol., 271, 407-417.

Simon J.C., Delmotte F., Rispe C. and Crease T., 2003. Phylogenetic relationships between parthenogens and their sexual relatives: the possible routes to parthenogenesis in animals. Biol. J. Linn. Soc., 79, 151-163.

Skurdal J. and Taugbol T., 2002. Astacus. In: Holdich D.M. (ed.), Biology of freshwater crayfish. Blackwell Science Ltd., Oxford, UK, pp. 467-510.

Smith D.G., 1979. Brief Note New Locality Records of Crayfishes from the Middle Hudson River System.

Smith D.G., 1981. Evidence for Hybridization Between Two Crayfish Species (Decapoda: Cambaridae: Orconectes) with a Comment on the Phenomenon in Cambarid Crayfish. The American Midland Naturalist, University of Notre Dame, 105 (2), 405-407.

Sokol A., 1988. The australian yabby. In: Holdich D.M. and Lowery R.S. (eds.), Freshwater Crayfish: Biology, Management and Exploitation. Croom-Helm, London, Sydney.

Suomalainen E., 1950. Parthenogenesis in animals. Adv. Genet., 3, 193-253.

Suomalainen E., Saura A. and Lokki J., 1987. Cytology and evolution in parthenogenesis. CRC, Boca Raton, FL.

Taketomi Y., 1986. Ultrastructure of the androgenic gland of the crayfish, Procambarus clarkii. Cell Biol. Int. Rep., 10, 131-136.

Taketomi Y., Nishikawa S. and Koga S., 1996. Testis and Androgenic Gland during Development of External Sexual Characteristics of the Crayfish Procambarus clarkii. J. Crustacean Biol., 16, 24-34.

Tan-Fermin J.D., 1991. Effects of unilateral eyestalk ablation on ovarian histology and oocyte size frequency of wild and pondreared Penaeus monodon (Fabricius) broodstock. Aquaculture, $93,77-86$.

Terauchi A., Tsutsumi H., Yang W.-J., Aida K., Nagasawa H. and Sonobe H., 1996. A Novel Neuropeptide with Molt-inhibiting Activity from the Sinus Gland of the Crayfish. Procambarus clarkii. Zool. Sci., 13, 295-298.

Tirelli T., Pessani D., Silvestro D. and Tudge C., 2008. Reproductive Biology of Mediterranean Hermit Crabs: Fine Structure of Spermatophores and Spermatozoa of Diogenes pugilator (Decapoda: Anomura) and Its Bearing on a Sperm Phylogeny of Diogenidae. J. Crustacean Biol., 28, 534-542.

Tudge C.C., 1995. ltrastructure and phylogeny of the spermatozoa of the infraorders Thalassinidea and Anomura (Decapoda, Crustacea). In: Jamieson B.G.M., Ausio J. and Justine J.-L. (eds.), I. Advances in spermatozoal phylogeny and taxonomy. Mémoires du Muséum National d'Histoire Naturelle Paris, 166, 251-263.

Tudge C.C., 2009. Spermatozoal morphology and its bearing on decapod phylogeny. In: Martin J.W., Crandall A. and Felder D.L. (eds.), Crustacean Issues: Decapod Crustacean Phylogenetics. Francis \& Taylor/CRC Press, Boca Raton, pp. 101-119.

Turgeon, J., and Hebert, P.D., 1994. Evolutionary interactions between sexual and all-female taxa of Cyprinotus (Ostracoda: Cyprididae). Evolution, 1855-1865.

Uma K. and Subramoniam T., 1979. Histochemical characteristics of spermatophore layers of Scylla serrata (Forskal) (Decapoda: Portunidae). Int. J. Inver. Rep. Dev., 1, 31-40.

Vanichviriyakit R., Kruevaisayawan H., Weerachatyanukul W., Tawipreeda P., Withyachumnarnkul B., Pratoomchat B., Chavadej J. and Sobhon P., 2004. Molecular modification of Penaeus monodon sperm in female thelycum and its consequent responses. Mol. Reprod. Dev., 69, 356-363.

Velisek J., Kouba A. and Stara A., 2013. Acute toxicity of triazine pesticides to juvenile signal crayfish (Pacifastacus leniusculus). Neuro. Endocrinol. Lett., 2, 31-36.

Vogt V., 2002. Functional anatomy. In: Holdich D.M. (ed.), Biology of freshwater crayfish, Blackwell Science, Oxford. 53-151.

Vogt G., 2007. Exposure of the eggs to 17a-methyl testosterone reduced hatching success and growth and elicited teratogenic effects in postembryonic life stages of crayfish. Aquat. Toxicol., 85, 291-296. 
Vogt G., Tolley L. and Scholtz G., 2004. Life stages and reproductive components of the Marmorkrebs (marbled crayfish), the first parthenogenetic decapod crustacean. J. Morphol., 261, 286-311.

Vogt G., Huber M., Thiemann M., van den Boogaart G., Schmitz O.J., and Schubart C.D., 2008. Production of different phenotypes from the same genotype in the same environment by developmental variation. J. Exp. Biol., 211, 510-523.

Vogt G., Falckenhayn C., Schrimpf A., Schmid K., Hanna K., Panteleit J., Helm M., Schulz R. and Lyko F., 2015. The marbled crayfish as a paradigm for saltational speciation by autopolyploidy and parthenogenesis in animals. Biology Open, 4 , $1583-1594$.

Wainwright G., Webster S.G., Wilkinson M.C., Chung J.S., Rees H.H., 1996. Structure and significance of mandibular organinhibiting hormone in the crab, Cancer pagurus. Involvement in multihormonal regulation of growth and reproduction. J. Biol. Chem., 271, 12749-12754.

Werner B., 1955. On the development and reproduction of the anthomedusan Margelopsis haeckeli Hartlaub. Annals of the New York Academy of Sciences, 62(1), 3-29.

Wetzel J.E., 2002. Form alteration of adult female crayfishes of the genus Orconectes (Decapoda: Cambaridae). Am. Midl. Nat., 147, 326-337.
Wilder N.M., Okumura T., Suzuki Y., Fusetani N. and Aida K., 1994. Vitellogenin Production Induced by Eyestalk Ablation in Juvenile Giant Freshwater Prawn Macrobrachium rosenbergii and Trial Methyl Farnesoate Administration. Zool. Sci., 11, 45-53.

Winterbourn M., 1970. The New Zealand species of Potamopyrgus (Gastropoda: Hydrobiidae). Malacologia, 10(2), 283-321.

Yasuzumi G. and Lee K.J., 1966. Spermatogenesis in animals as revealed by electron microscopy. XVI. The microtubular structure and sites of thiamine pyrophosphatase activity in premature sperm of the Japanese crayfish. Z. Zellforsch. Mik. Ana., 73, 384-404.

Yazicioglu B., Linhartova Z., Niksirat H. and Kozák P., 2014. First report of intersex in the signal crayfish Pacifastacus leniusculus (Dana, 1862). Crustaceana, 87, 1559-1566.

Yue G.H., Wang G.L., Zhu B.Q., Wang C.M., Zhu Z.Y. and Lo L.C., 2008. Discovery of four natural clones in a crayfish species Procambarus clarkii. Int. J. Biol. Sci., 4, 279-282.

Yue G.H., Li J., Bai Z., Wang C.M. and Feng F., 2010. Genetic diversity and population structure of the invasive alien red swamp crayfish. Biol. Invas., 12, 2697-2706.

Zuber S.T., Muller K., Laushman R.H. and Roles A.J., 2012. Hybridization between an invasive and a native species of the crayfish genus Orconectes in North-Central Ohio. J. Crustacean Biol., 32, 962-971.

Cite this article as: B. Yazicioglu, J. Reynolds, P. Kozák, 2016. Different aspects of reproduction strategies in crayfish: A review. Knowl. Manag. Aquat. Ecosyst., 417, 33. 